\title{
Serogroups, virulence genes and antibiotic resistance in Shiga toxin-producing Escherichia coli isolated from diarrheic and non-diarrheic pediatric patients in Iran
}

\author{
Hassan Momtaz ${ }^{1 *}$, Farhad Safarpoor Dehkordi ${ }^{2}$, Mohammad Javad Hosseini ${ }^{3}$, Meysam Sarshar ${ }^{3}$
} and Maliheh Heidari ${ }^{4}$

\begin{abstract}
Background: From a clinical perspective, it is important to know which serogroups, virulence genes and antibiotic resistance patterns are present in Shiga toxin-producing Escherichia coli strains in pediatric patients suffering from diarrheic and non-diarrheic infections. This is the first study in Iran that has comprehensively investigated the Shiga toxin-producing Escherichia coli -related infection characteristics in diarrheic and non-diarrheic pediatric patients of 0-60 months of age.

Methods: Two-hundred and twenty four diarrheic and 84 non-diarrheic stool specimens were collected from the Baqiyatallah hospital of Tehran, Iran. The stool samples were cultured immediately and those that were E. coli-positive were analyzed for the presence of antibiotic resistance genes and bacterial virulence factors using PCR. Antimicrobial susceptibility testing was performed using disk diffusion method.

Results: One-hundred and fifty four out of 224 (68.75\%) diarrheic stools and 31 out of 84 (36.90\%) non-diarrheic stools harbored E. coli. In addition, children in 13-24 month-old age group had the highest incidence of infection with this bacterium (77.63\%). A significant difference was found between the frequency of Attaching and Effacing Escherichia coli and Enterohaemorrhagic Escherichia coli $(P=0.045)$. The genes encoding Shiga toxins and intimin were the most commonly detected virulence factors. Among all serogroups studied, O26 (27.04\%) and O111 (18.85\%) had the highest incidences in the diarrheic and non-diarrheic patients. The incidence of genes encoding resistance against sulfonamide (sul1), gentamicin (aac(3)-IM), trimethoprim (aadA1), cephalothin (blaSHV) and tetracycline (tetA) were 82.78\%, 68.03\%, $60.65 \%, 56.55 \%$ and $51.63 \%$, respectively. High resistance levels against penicillin (100\%), tetracycline (86.88\%), gentamicin (62.29\%) and streptomycin (54.91\%) were observed. Marked seasonality in the serogroup distributions was evident, while STEC infections were more common in summer ( $P=0.041)$.
\end{abstract}

Conclusions: Our findings should raise awareness about antibiotic resistance in diarrheic pediatric patients in Iran. Clinicians should exercise caution when prescribing antibiotics, especially during the warmer months of the year.

Keywords: Shiga toxin-producing Escherichia coli, Diarrhea, Pediatric patients, Iran

\footnotetext{
* Correspondence: hamomtaz@yahoo.com

'Department of Microbiology, Shahrekord Branch, Islamic Azad University,

P.O. Box 166, Shahrekord, Iran

Full list of author information is available at the end of the article
}

\section{Biomed Central}

(c) 2013 Momtaz et al.; licensee BioMed Central Ltd. This is an Open Access article distributed under the terms of the Creative Commons Attribution License (http://creativecommons.org/licenses/by/2.0), which permits unrestricted use, distribution, and reproduction in any medium, provided the original work is properly cited. The Creative Commons Public Domain Dedication waiver (http://creativecommons.org/publicdomain/zero/1.0/) applies to the data made available in this article, unless otherwise stated. 


\section{Background}

Infection with Shiga toxin (Stx)-producing Escherichia coli (STEC) can result in a spectrum of outcomes, ranging from asymptomatic carriage to uncomplicated diarrhea, hemolytic uremic syndrome (HUS), bloody diarrhea, hemolytic anemia, thrombocytopenia, and acute renal failure [1-4]. High mortality and morbidity rates have been reported for HUS, which can occur from infection with STEC strains $[1,5]$. The pathogenesis of STEC is related to several bacterial virulence factors $[4,6]$. Some of the most important of these virulence factors include the intimin (eae) protein, two shiga toxins called stx 1 and $s t x 2$, and the plasmid-encoded protein known as hemolysin $(e h l y)[4,6]$.

Most outbreaks and sporadic cases of bloody and nonbloody diarrhea and HUS have been attributed to strains of the STEC serogroup O157 [7,8]. However, non-O157 strains such as O26, O111, O145, O26, O91, O103, O113, O128, O121 and O45 have been shown to cause bloody and non-bloody diarrhea and HUS $[7,8]$. If diarrheic patients do not receive effective treatment, they are susceptible to secondary infections and illnesses.

Diseases caused by $E$. coli often require antimicrobial therapy; however, antibiotic-resistant strains of this bacterium cause longer and more severe illnesses than their antibiotic-susceptible counterparts. Several studies have shown that antibiotic resistance in E. coli has increased over time [8-10]. In keeping with this, an epidemiological investigation in Iran revealed that STEC strains were the most commonly detected strains in pediatric patients with diarrhea and that there was a high incidence of resistance $(85-100 \%)$ to commonly used antibiotics $[11,12]$. Antibiotic resistance genes are known to cause antibiotic resistance in STEC strains isolated from diarrheic patients [13].

Data on the distribution of serogroups, virulence genes and the antimicrobial resistance properties of STEC strains isolated from pediatric patients are scarce in Iran [11]. Therefore, the aim of the present study was to characterize STEC strains isolated from Iranian diarrheic and nondiarrheic pediatric patients at the molecule level and investigate their susceptibility to 12 commonly used antibiotics, as well as investigating seasonal variation in the prevalence and serogroups distribution of E. coli.

\section{Methods}

\section{Sample collection, preparation, and identification of E. coli serogroups}

From March 2012 to March 2013, a period covering seasonal variation, 308 stool samples from diarrheic and non-diarrheic pediatric patients were collected from the Baqiyatallah hospital in Tehran, Iran. Stool samples were classified as either diarrheic or non-diarrheic. Individuals from the diarrheic group were placed into six groups based on their ages $(1-12,13-24,25-36,37-48$ and 49-60 month-old children) (Table 1). Information on
Table 1 Incidence of $E$. coli isolated from diarrheic and non-diarrheic children

\begin{tabular}{ccc}
\hline Age group (Months) & No. samples & No. positive samples \\
\hline $\mathbf{1 - 1 2}$ & 52 & $36(69.23 \%)$ \\
$\mathbf{1 3 - 2 4}$ & 76 & $59(77.63 \%)$ \\
$\mathbf{2 5 - 3 6}$ & 39 & $24(61.53 \%)$ \\
$\mathbf{3 7 - 4 8}$ & 24 & $16(66.66 \%)$ \\
$\mathbf{4 9 - 6 0}$ & 33 & $19(57.57 \%)$ \\
Total diarrheic samples & 224 & $154(68.75)$ \\
Non diarrheic & 84 & $31(36.90 \%)$ \\
Total & 308 & $185(60.06 \%)$ \\
\hline
\end{tabular}

the clinical and epidemiological history of these patients was obtained through questionnaires. Patients presented at the hospital with symptoms such as nausea and fever, while others had dysentery-like or inconsequential symptoms. Stool specimens were collected using sterile rectal swabs, which were transferred to tubes containing Stuart medium (Merck, Germany). Samples were transferred to the Biotechnology and Microbiology Research Center of the Islamic Azad University of Shahrekord at $4^{\circ} \mathrm{C}$. All samples were diluted in phosphate buffered saline (PBS, Merck, Germany). The samples were plated onto MacConkey's agar (MC, Merck, Germany) and incubated overnight at $37^{\circ} \mathrm{C}$. A lactose positive colony was selected from each sample, streaked onto Eosin Methylene Blue (EMB, Merck, Germany) plates and incubated overnight at $37^{\circ} \mathrm{C}$. Green colonies with a metallic luster were considered as typical E. coli colonies. Such colonies were confirmed as E. coli using standard biochemical tests (e.g., Methyl red, Voges-Proskauer, Indole, and Citrate utilization tests). Colonies were confirmed as E. coli by PCR [14]. E. coli isolates were stored in Tryptic Soy Broth (TSB, Merck, Germany) containing $20 \%$ glycerol at $-70^{\circ} \mathrm{C}$ for further characterization.

\section{Antimicrobial susceptibility testing}

Antimicrobial susceptibility testing of the isolates was performed using the Kirby-Bauer disc diffusion method and Mueller-Hinton agar (Merck, Germany) according to Clinical and Laboratory Standards Institute (CLSI) instructions [15]. Inoculated plates were incubated aerobically at $37^{\circ} \mathrm{C}$ for $18-24 \mathrm{~h}$, after which antimicrobial susceptibility in the E. coli isolates were tested. Tetracycline $(30 \mu \mathrm{g} /$ disk $)$, ampicillin $(10 \mathrm{u} /$ disk $)$, penicillin (10 u/disk), sulfamethoxazole ( $25 \mu \mathrm{g} /$ disk), streptomycin $(10 \mu \mathrm{g} /$ disk $)$, sulfonamide (100 $\mu \mathrm{g} /$ disk), chloramphenicol $(30 \mu \mathrm{g} /$ disk $)$, gentamicin $(10 \mu \mathrm{g} /$ disk $)$, trimethoprim (5 $\mu \mathrm{g} /$ disk), ciprofloxacin (5 $\mu \mathrm{g} /$ disk), enrofloxacin (5 $\mu \mathrm{g} /$ disk), cephalothin (30 $\mu \mathrm{g} /$ disk), and nitrofurantoin $(300 \mu \mathrm{g} / \mathrm{disk})$ were tested. The results were interpreted in accordance with CLSI criteria [16]. E. coli ATCC 25922 
was used as quality control for antimicrobial susceptibility determination.

\section{DNA extraction}

Bacterial strains were grown overnight in Trypticase Soy Agar (TSA, Merck, Germany) at $37^{\circ} \mathrm{C}$. A single colony was suspended in $100 \mu \mathrm{L}$ of sterile distilled water. After boiling the suspension for $13 \mathrm{~min}$, the suspension was frozen and centrifuged at $14,000 \mathrm{rpm}$ for $15 \mathrm{~min}$ to pellet the cell debris [17]. The supernatant was used as a template for PCR amplification.

\section{PCR detection of serogroups, virulence factors and antibiotic resistance genes in STEC strains}

To detect virulence factors, serogroups, and antibiotic resistance genes in the E. coli isolates, different PCR assays were used [16,18-29]. All the PCR products were electrophoresed on $1.5 \%$ agarose gels that were strained with ethidium bromide and examined under ultraviolet illumination. E. coli O159:H20, O157:K88ac:H19, CAPM 6006, and CAPM 5933 strains were used as positive controls and distilled water was used as a negative control.

\section{Statistical analyses}

The data were analyzed using SPSS (Statistical Package for the Social Sciences) software and $P$ values were calculated using Chi-square and Fisher's exact tests to identify statistically significant relationships between the following: patient ages, seasonal variations, patient symptoms and distribution of virulence genes, serogroups and antibiotic resistance properties of the STEC strains isolated from diarrheic and non-diarrheic pediatric patients. A $P$ value $<0.05$ was considered statistically significant.

\section{Ethical considerations}

The present study was authorized by the ethical committee of the Baqiyatallah hospital of Tehran, Iran and the Microbiology, Biotechnology and Infectious Diseases Center of the Islamic Azad University of Shahrekord Branch, Iran. All patients or their parents signed the written informed consent.

\section{Results and discussion}

All of the diarrheic and non-diarrheic stool samples were examined using culture and PCR techniques. From 308 diarrheic and non-diarrheic stool samples, 185 (60.06\%) were positive for E. coli (Table 1). In addition, 154 out of 224 diarrheic stool samples $(68.75 \%)$ and 31 out of 84 non-diarrheic stool samples $(36.90 \%)$ were positive for E. coli. The age distribution of the pediatric patients with regard to infection with $E$. coli is shown in Table 1 . We found that the 13-24 month-old patients had the highest incidence of E. coli (77.63\%), while the 49-60 month-old children had the lowest incidence (57.57\%).
The distribution of virulence genes in the $E$. coli subtypes isolated from diarrheic and non-diarrheic pediatric patients is shown in Table 2. We found that stx 1 and eaeA were the most commonly detected virulence genes in stool samples from both groups of children. The Attaching and Effacing E. coli (AEEC) subtype was the most commonly detected. The EHEC subtype was only detected in the 13-24, 25-36, and 49-60 month-old patients.

Table 3 shows the incidence of STEC serogroups isolated from diarrheic and non-diarrheic patients. O26 (27.04\%) had the highest incidence, followed by O111 (18.85\%). We also found that 13-24 month-old patients had the highest incidence of the STEC serogroups. The distribution of antimicrobial resistance genes within the STEC serogroup isolated from diarrheic and non-diarrheic pediatric patients is shown in Table 4. Genes that encode resistance to sulfonamide, gentamicin, trimethoprim, cephalothin and tetracycline antibiotics, i.e., sul1 (82.78\%), aac(3)-IV (68.03\%), aadA1 (60.65\%), blaSHV (56.55\%) and tetA (51.63\%) were the most common antibiotic resistance genes in the diarrheic and non-diarrheic patients. Interestingly, we found that $\mathrm{O} 26$ had the highest frequency of antibiotic resistance genes. Antimicrobial resistance in the STEC serogroups isolated from the diarrheic and non-diarrheic patients is shown in Table 5. STEC strains exhibited the highest level of resistance to penicillin (100\%), followed by tetracycline (86.88\%), gentamicin (62.29\%) and streptomycin (54.91\%). Descriptions of the seasonal profiles and clinical signs in diarrheic children for each serogroup are shown in Table 6. Samples that were collected in the summer had the highest incidence of STEC serogroups, while those collected in autumn had the lowest incidence. Children with fever symptom had the highest incidence of STEC serogroups. Distribution of antimicrobial resistance pattern of STEC strains in various clinical samples are shown in Table 7. We found that the STEC strains of dysentery and fever samples had the highest levels of antibiotic resistance. The highest levels of antibiotic resistance of the STEC strains isolated from children with dysentery were found against streptomycin, sulfamethoxazole, gentamicin, cephalothin, nitrofurantoin and ampicillin.

Our work has identified marked seasonality in the incidence of STEC serogroup strains in diarrheic and non-diarrheic pediatric patients. There were significant differences $(P=0.041)$ in the incidence of STEC serogroup strains between the hot and cold seasons of the year. One possible explanation for the high prevalence of STEC serogroups in summer in Iran is that climatic variables such as heat, rain and thunderstorms, together with variable barometric pressure may have affected the patients' autonomic nervous systems. These variables could affect immunity, thus making people more susceptible to infections. Alternatively, the higher prevalence of STEC serogroups may be related to higher growth rates in the 
Table 2 Distribution of virulence factors in E. coli subtypes

\begin{tabular}{ccc}
\hline Age (Month) & Subtype & No. Positive samp \\
\hline Non detected & $12(33.66 \%)$ \\
EHEC & - \\
$\mathbf{1 - 1 2} \mathbf{5 2})$ & AEEC & $24(66.66 \%)$ \\
& & \\
& & \\
& Total & $36(69.23 \%)$ \\
Non detected & $18(30.50 \%)$ \\
EHEC & $2(3.38 \%)$ \\
AEEC & $39(66.10 \%)$
\end{tabular}

13-24 (76)

25-36 (39)

37-48 (24)
Virulence gene

stx1, eaeA, ehly: -

$$
\begin{gathered}
\text { stx1: } 18(75.00 \%) \\
\text { stx2: } 2(8.33 \%) \\
\text { eaeA: } 14(58.33 \%) \\
\text { stx1, eaeA: } 15(62.50 \%) \\
\text { stx2, eaeA: } 7(29.16 \%)
\end{gathered}
$$

stx1, st×2, eaeA: 2 (8.33\%)

stxl, eaeA, ehly: 2 (100\%)

$$
\begin{gathered}
\text { stx1: } 29(74.35 \%) \\
\text { stx2: } 4(10.25 \%) \\
\text { eaeA: } 24(61.53 \%) \\
\text { stx1, eaeA: } 27(69.23 \%) \\
\text { stx2, eaeA: } 8(20.51 \%)
\end{gathered}
$$

$s t \times 1$, stx2, eaeA: 4 (10.25\%)

$59(77.63 \%)$

$6(25.00 \%)$

1 (4.16\%)

$17(70.83 \%)$

stx1, eaeA, ehly: 1 (100\%)

$$
\begin{gathered}
s t \times 1: 13(76.47 \%) \\
s t \times 2: 2(11.76 \%) \\
\text { eaeA: } 12(70.58 \%) \\
s t \times 1, \text { eaeA: } 7(41.17 \%) \\
s t \times 2, \text { eaeA: } 8(47.05 \%) \\
s t \times 1, \text { stx2, eaeA: } 2(11.76 \%)
\end{gathered}
$$

$24(61.53 \%)$

$4(25.00 \%)$
$12(75.00 \%)$

$$
\begin{gathered}
\text { stx1, eaeA, ehly: - } \\
\text { stx1: } 8(66.66 \%) \\
\text { stx2: } 1(8.33 \%) \\
\text { eaeA: } 6(50.00 \%) \\
\text { stx1, eaeA: } 6(50.00 \%) \\
\text { stx2, eaeA: } 5(41.66 \%) \\
\text { stx1, stx2, eaeA: } 1(8.33 \%)
\end{gathered}
$$

$16(66.66 \%)$ 
Table 2 Distribution of virulence factors in E. coli subtypes (Continued)

\begin{tabular}{|c|c|c|c|}
\hline & Non detected & $7(36.84 \%)$ & - \\
\hline & EHEC & $3(15.78 \%)$ & \\
\hline & & & stx1, eaeA, ehly: $3(100 \%)$ \\
\hline & AEEC & $9(47.36 \%)$ & \\
\hline \multirow[t]{11}{*}{$49-60(33)$} & & & stx1: 7 (77.77\%) \\
\hline & & & stx2: $1(11.11 \%)$ \\
\hline & & & eaeA: 6 (66.66\%) \\
\hline & & & stx1, eaeA: 4 (44.44\%) \\
\hline & & & stx2, eaeA: 4 (44.44\%) \\
\hline & & & stx1, stx2, eaeA: 1 (11.11\%) \\
\hline & Total & $19(57.57 \%)$ & \\
\hline & Non detected & $16(51.61 \%)$ & \\
\hline & EHEC & & \\
\hline & & & stx1, eaeA, ehly \\
\hline & AEEC & $15(48.38 \%)$ & \\
\hline \multirow[t]{7}{*}{ Non diarrheic (84) } & & & stx1: $12(80.00 \%)$ \\
\hline & & & stx2: 2 (13.33\%) \\
\hline & & & eaeA: $13(86.66 \%)$ \\
\hline & & & stx1, eaeA: 7 (46.66\%) \\
\hline & & & stx2, eaeA: 6 (40.00\%) \\
\hline & & & stx1, stx2, eaeA: $2(13.33 \%)$ \\
\hline & Total & $31(36.90 \%)$ & \\
\hline
\end{tabular}

bacteria. Therefore, the highest levels of pediatric health care should be performed during the warmer months of year. Of the studies that have been conducted [30,31] in this field, all have shown a seasonal distribution for E. coli with the highest numbers of cases occurring during the warmer months of the year [30,31].

Data from 1996 to 2011 shows a seasonal increase in cases from April to November in Louisiana, USA [30]. Our results show that fever was most commonly associated with the highest incidence of STEC serogroup types (Table 7). This finding is in accordance with the results of Rivas et al. [32].
The most commonly infected group was 13-24 monthold age group (77.63\%), but there were no significant differences in the incidence of STEC strains among the various age groups. In addition, $68.75 \%$ of diarrheic and $36.90 \%$ of non-diarrheic stool samples from the children were positive for $E$. coli strains; hence, the diarrheic patients showed the higher incidence of E. coli $(P=0.022)$. Lower incidence of STEC strains in Iranian diarrheic children were reported previously by Salmanzadeh-Ahrabi et al. [33] (15.5\% incidence rate in pediatrics under 5 years old) and Alikhani et al. [34] (8.7\% incidence rate in pediatrics under 10 years old).

Table 3 Incidence of Shiga toxin-producing $E$. coli serogroups

\begin{tabular}{ccccccccccc}
\hline Age (Month) & $\mathbf{0 1 5 7}$ & $\mathbf{0 2 6}$ & $\mathbf{0 1 0 3}$ & $\mathbf{0 1 1 1}$ & $\mathbf{0 1 4 5}$ & $\mathbf{0 4 5}$ & $\mathbf{0 9 1}$ & $\mathbf{0 1 1 3}$ & $\mathbf{0 1 2 1}$ & $\mathbf{0 1 2 8}$ \\
\hline $\mathbf{1 - 1 2}(\mathbf{2 4 )}$ & - & 7 & 2 & 5 & 2 & 1 & 3 & 2 & 1 \\
$\mathbf{1 3 - 2 4}(\mathbf{4 1})$ & 2 & 10 & 3 & 7 & 4 & 4 & 5 & 1 & 3 & 2 \\
$\mathbf{2 5 - 3 6 ( 1 8 )}$ & 1 & 4 & 2 & 3 & - & 1 & 3 & - & 4 \\
$\mathbf{3 7 - 4 8}(\mathbf{1 2})$ & - & 4 & - & - & 2 & 1 & 1 & - & 2 & 2 \\
$\mathbf{4 9 - 6 0}(\mathbf{1 2})$ & 3 & 2 & 1 & 2 & - & 1 & - & 1 & 1 & - \\
Non diarrheic (15) & - & 6 & - & 6 & - & 3 & - & - & - \\
Total (122) & $6(4.91 \%)$ & $33(27.04 \%)$ & $8(6.55 \%)$ & $23(18.85 \%)$ & $8(6.55 \%)$ & $11(9.01 \%)$ & $12(9.83 \%)$ & $4(3.27 \%)$ & $11(9.01 \%)$ & $6(4.91 \%)$ \\
\hline
\end{tabular}


Table 4 Distribution of antimicrobial resistance genes in Shiga toxin-producing $E$. coli serogroups

\begin{tabular}{|c|c|c|c|c|c|c|c|c|c|c|c|}
\hline Serogroups & aadA1 & tet $A$ & tet $B$ & dfrA1 & $q n r$ & $\operatorname{aac}(3)-I V$ & sul1 & blaSHV & CITM & cat1 & $\mathrm{cmlA}$ \\
\hline 0157 (6) & 2 & 2 & 2 & - & - & 2 & - & 4 & 2 & - & - \\
\hline $026(33)$ & 25 & 18 & 17 & 12 & 8 & 29 & 31 & 19 & 22 & 1 & - \\
\hline $0103(8)$ & 4 & 8 & - & - & - & 3 & 2 & 5 & 4 & - & - \\
\hline 0111 & 11 & 7 & 10 & 8 & 6 & 16 & 20 & 12 & 11 & - & - \\
\hline $0145(8)$ & 4 & 6 & 4 & 6 & - & - & 8 & 6 & 3 & - & - \\
\hline 045 (11) & 5 & 7 & 4 & 9 & - & 8 & 10 & 8 & 5 & - & - \\
\hline 091 (12) & 5 & 6 & 5 & 4 & 1 & 11 & 10 & 8 & 6 & - & 1 \\
\hline $0113(4)$ & 4 & 2 & 2 & - & - & 4 & 4 & 3 & 1 & - & - \\
\hline $0121(11)$ & 9 & 6 & - & 4 & - & 7 & 10 & 4 & 3 & - & - \\
\hline $0128(6)$ & 5 & 1 & 3 & 1 & - & 3 & 6 & - & 2 & - & - \\
\hline Total (122) & $\begin{array}{c}74 \\
(60.65 \%)\end{array}$ & $\begin{array}{c}63 \\
(51.63 \%)\end{array}$ & $\begin{array}{c}47 \\
(38.52 \%)\end{array}$ & $\begin{array}{c}44 \\
(36.06 \%)\end{array}$ & $\begin{array}{c}15 \\
(12.29 \%)\end{array}$ & $\begin{array}{c}83 \\
(68.03 \%)\end{array}$ & $\begin{array}{c}101 \\
(82.78 \%)\end{array}$ & $\begin{array}{c}69 \\
(56.55 \%)\end{array}$ & $\begin{array}{c}59 \\
(48.36 \%)\end{array}$ & $\begin{array}{c}1 \\
(0.81 \%)\end{array}$ & $\begin{array}{c}1 \\
(0.81 \%)\end{array}$ \\
\hline
\end{tabular}

Another important finding relates to the distributions of four bacterial virulence factors (stx1, stx2, ehly and eaeA) in the diarrheic and non-diarrheic patients. We found statistically significant $(P=0.016)$ association between the incidence of stx 1 and stx 2 genes in all groups and between the EHEC and AEEC subtypes $(P=0.045)$. In addition, there were significant differences amongst the incidence of virulence factors in diarrheic and nondiarrheic patients $(P=0.047)$. Sang et al. [35] reported that 141 out of 380 diarrheic patients (37.1\%) were positive for E. coli and of these, ETEC, STEC, EAEC, EIEC and EPEC strains comprised 29.8\%, 24.1\%, 14.2\% $12.8 \%$ and $3.5 \%$, respectively. The presence of multiple stx 1, eaeA, and ehly genes was found in the EHEC strains isolated from 13-24 (100\%), 25-36 (100\%) and 49-60 month-old (100\%) patients. Additionally, 13.33\% of non- diarrheic, $11.11 \%$ of 49-60 month-old diarrheic,
$8.33 \%$ of $37-48$ month-old diarrheic, $11.76 \%$ of $25-36$ month-old diarrheic, $10.25 \%$ of $13-24$ month-old diarrheic and $8.33 \%$ of $1-12$ month-old diarrheic patients harbored stx 1, stx 2 and eaeA genes. Similar findings have been reported in various parts of the world including Kenya, Korea, Australia and Brazil [35-38]. Of several studies which were conducted in this field in Iran. Shams et al. [39] showed that $2.8 \%$ of STEC isolates were positive for $s t x 1$ or $s t x 2$ genes, Aslani and Bouzari [40] showed that $96.5 \%$ of STEC isolates had stx 1 gene, $44.8 \%$ had hly gene, $3.5 \%$ had stx 2 , and $24.1 \%$ had ast 1 gene and Bonyadian et al. [41] reported that $27.6 \%$ of STEC isolates had st $x 1$ gene, $20.7 \%$ had $h l y$ gene and $6.9 \%$ had stx 2 which all was lower than our results. These studies indicate that the stx 1 , $s t x 2$, hly and eaeA genes are only present in some of the groups studied and that the eaeA and ehly genes are associated with diarrhea. Within the disease-associated strains,

Table 5 Antimicrobial resistance properties in Shiga toxin-producing $E$. coli serogroups

\begin{tabular}{|c|c|c|c|c|c|c|c|c|c|c|c|c|}
\hline Serogroups & TE30* & S10 & C30 & SXT & GM10 & NFX5 & CF30 & CIP5 & TMP5 & F/M300 & AM10 & P10 \\
\hline 0157 (6) & 4 & 2 & - & - & 2 & - & 3 & - & - & - & 2 & 6 \\
\hline 026 (33) & 32 & 24 & 1 & 29 & 26 & 3 & 17 & - & 11 & 1 & 18 & 33 \\
\hline $0103(8)$ & 8 & 3 & - & 1 & 3 & - & 4 & 1 & - & - & 2 & 8 \\
\hline $0111(23)$ & 16 & 11 & - & 19 & 14 & 2 & 11 & 2 & 8 & - & 8 & 23 \\
\hline 0145 (8) & 8 & 4 & - & 8 & - & - & 4 & - & 4 & 1 & 2 & 8 \\
\hline O45 (11) & 10 & 5 & - & 11 & 7 & 1 & 7 & - & 8 & - & 2 & 11 \\
\hline 091 (12) & 10 & 4 & 1 & 8 & 10 & 1 & 6 & - & 4 & - & 6 & 12 \\
\hline $0113(4)$ & 4 & - & - & 3 & 4 & - & 2 & - & - & - & 1 & 4 \\
\hline $0121(11)$ & 9 & 9 & - & 10 & 7 & 1 & 2 & - & 3 & - & 3 & 11 \\
\hline $0128(6)$ & 5 & 5 & - & 5 & 3 & - & - & - & 1 & - & - & 6 \\
\hline Total (122) & $\begin{array}{c}106 \\
(86.88 \%)\end{array}$ & $\begin{array}{c}67 \\
(54.91 \%)\end{array}$ & $\begin{array}{c}2 \\
(1.63 \%)\end{array}$ & $\begin{array}{c}94 \\
(77.04 \%)\end{array}$ & $\begin{array}{c}76 \\
(62.29 \%)\end{array}$ & $\begin{array}{c}8 \\
(6.55 \%)\end{array}$ & $\begin{array}{c}56 \\
(45.90 \%)\end{array}$ & $\begin{array}{c}3 \\
(2.45 \%)\end{array}$ & $\begin{array}{c}39 \\
(31.96 \%)\end{array}$ & $\begin{array}{c}2 \\
(1.63 \%)\end{array}$ & $\begin{array}{c}44 \\
(36.06 \%)\end{array}$ & $\begin{array}{c}122 \\
(100 \%)\end{array}$ \\
\hline
\end{tabular}

${ }^{*} T E 30=$ tetracycline $(30 \mu \mathrm{g} /$ disk); $S 10=(10 \mu \mathrm{g} /$ disk); $C 30=$ chloramphenicol (30 $\mu \mathrm{g} /$ disk); SXT = sulfamethoxazole $(25 \mu \mathrm{g} /$ disk); GM10 = gentamycin (10 $\mu \mathrm{g} / \mathrm{disk}) ;$ NFX5 = enrofloxacin $(5 \mu \mathrm{g} /$ disk); $C F 30=$ cephalothin $(30 \mu \mathrm{g} /$ disk $) ; C I P 5=$ ciprofloxacin $(5 \mu \mathrm{g} /$ disk $) ; T M P 5=$ trimethoprim $(5 \mu \mathrm{g} /$ disk $) ; F / M 300=$ nitrofurantoin $(300 \mu \mathrm{g} /$ disk); $A M 10=$ ampicillin $(10 \mathrm{u} /$ disk); $P 10=$ penicillin $(10 \mathrm{u} /$ disk $)$. 
Table 6 Seasonal distribution of serogroups and clinical signs in diarrheic children

\begin{tabular}{|c|c|c|c|c|c|c|c|c|c|c|}
\hline Criteria & $\begin{array}{c}0157 \\
(6)\end{array}$ & $\begin{array}{l}026 \\
(27)\end{array}$ & $\begin{array}{c}0103 \\
(8)\end{array}$ & $\begin{array}{c}0111 \\
(17)\end{array}$ & $\begin{array}{c}0145 \\
(8)\end{array}$ & $\begin{array}{c}045 \\
(8)\end{array}$ & $\begin{array}{l}091 \\
(12)\end{array}$ & $\begin{array}{c}0113 \\
(4)\end{array}$ & $\begin{array}{c}0121 \\
(11)\end{array}$ & $\begin{array}{c}0128 \\
(6)\end{array}$ \\
\hline Spring (32) & - & 9 & - & 3 & 5 & 6 & 2 & - & 5 & 2 \\
\hline Summer (40) & 4 & 10 & 3 & 5 & 2 & 1 & 7 & 2 & 3 & 3 \\
\hline (Autumn) (17) & - & 2 & 3 & 9 & - & 1 & - & - & 1 & 1 \\
\hline Winter (18) & 2 & 6 & 2 & - & 1 & - & 3 & 2 & 2 & - \\
\hline Nausea (42) & - & 7 & 1 & 6 & 5 & 5 & 5 & 3 & 7 & 3 \\
\hline Fever (34) & 2 & 17 & 1 & 8 & - & 1 & 3 & 1 & 1 & - \\
\hline Dysentery (14) & 4 & 3 & 1 & - & 2 & - & 2 & - & 1 & 1 \\
\hline Other clinical signs (17) & - & - & 5 & 3 & 1 & 2 & 2 & - & 2 & 2 \\
\hline
\end{tabular}

those containing stx 1 and $s t x 2$ (especially stx2) appear to be more commonly responsible for serious complications bloody and non-bloody diarrhea and HUS than those containing other putative bacterial pathogenic genes $[42,43]$.

O26 was the most commonly detected serogroup of all of the diarrheic and non-diarrheic STEC strains. Statistical analyses showed a significant $(P=0.028)$ association between the incidence of the O26 serogroup and other STEC serogroups in all of the study groups. High differences in the incidence of STEC serogroups between diarrheic and non-diarrheic patients was reported previously [44,45]. Aslani and Alikhani [46] reported that O142, O111, O86 and $\mathrm{O} 127$ were the most commonly detected serogroups in Iranian diarrheic children under 5 years of age which was in contrast with our results. High presence of $\mathrm{O} 55$, O26, O111, O125, O128, O114, O86, O142, O119, O127, and O126 serogroups was reported in the STEC strains of Alikhani et al. investigation [47].

In two studies involving 11 sites in the USA in 1997 and four sites during 1998-1999, screening of 13,798 stool samples for STEC yielded a frequency of $0.9 \%$ (120 cases of STEC), and of these 120 cases, from the isolates available, 54\% were O157 STEC, while 46\% were non-O157 STEC [45]. Many studies have shown that O26 is the most clinically important genotype within the STEC serogroup isolated from diarrheic and even non-diarrheic patients $[48,49]$ because of its association with bloody diarrhea, non-bloody diarrhea and HUS.

Because inappropriate prescriptions of antibiotics causes antibiotic resistance, it was not surprising that our study found that resistance to penicillin was $100 \%$, while resistance to tetracycline, gentamicin and streptomycin were $86.88 \%$, $62.29 \%, 54.91 \%$, respectively. In terms of bacterial antibiotic resistance genes, sul1 (82.78\%), aac(3)-IV (68.03\%), aadA1 (60.65\%), blaSHV (56.55\%) and tetA (51.63\%) were the most commonly detected. There were statistically significant differences $(P=0.029)$ amongst the incidences of sul1, cat1 and cmlA and among aac(3)-IV, cat1 and cmlA $(P=0.041)$. Our results showed that the $\mathrm{O} 26$ serogroup had the highest incidence of antibiotic resistance genes and resistance to antibiotics. Our results showed that $1.63 \%$ of the STEC strains were resistance to chloramphenicol. Chloramphenicol is a banned antibiotic and the slight antibiotic resistance to this drug detected in our study indicates that irregular and unauthorized use of it may have occurred in Iran. Similar chloramphenicol resistance profiles to our own have been reported previously [50,51]. Fazeli and Salehi [52] showed that 72.4\%, 65.5\% and $58.6 \%$ of STEC strains isolated from Iranian diarrheal patients were resistant to amoxicillin, trimethoprimsulfamethoxazole and tetracycline, respectively.

There were statistically significant differences $(P=0.040)$ amongst the incidences of antibiotic resistance in the

Table 7 Distribution of antimicrobial resistance pattern of Shiga toxin producing Escherichia coli in various clinical samples

\begin{tabular}{|c|c|c|c|c|c|c|c|c|c|c|c|c|}
\hline \multirow[t]{2}{*}{ Clinical signs } & \multicolumn{12}{|c|}{ Antibiotic resistance pattern (\%) } \\
\hline & TE30 & S10 & C30 & SXT & GM10 & NFX5 & CF30 & CIP5 & TMP5 & F/M300 & AM10 & P10 \\
\hline Nausea (42) & $33(78.57)$ & $15(35.71)$ & - & $28(66.66)$ & $13(30.95)$ & $1(2.38)$ & $11(26.19)$ & - & $9(21.42)$ & - & $10(23.80)$ & $42(100)$ \\
\hline Fever (34) & $34(100)$ & $22(64.70)$ & - & $32(94.11)$ & $27(79.41)$ & $2(5.88)$ & $17(50)$ & - & $10(29.41)$ & - & $11(32.35)$ & $34(100)$ \\
\hline Dysentery (14) & $14(100)$ & $14(100)$ & $1(7.14)$ & $14(100)$ & $14(100)$ & $3(21.42)$ & $12(85.71)$ & $2(14.28)$ & $11(78.57)$ & $2(14.28)$ & $13(92.85)$ & $14(100)$ \\
\hline $\begin{array}{l}\text { Other clinical } \\
\text { signs (17) }\end{array}$ & $17(100)$ & $12(70.58)$ & $1(5.88)$ & $16(94.11)$ & $14(82.35)$ & $2(11.76)$ & $13(76.47)$ & $1(5.88)$ & $7(41.17)$ & - & $7(41.17)$ & $17(100)$ \\
\hline Non diarrheic (15) & $8(53.33)$ & $4(26.66)$ & - & $4(26.66)$ & $8(53.33)$ & - & $3(20)$ & - & $2(13.33)$ & - & $3(20)$ & $15(100)$ \\
\hline Total (122) & $\begin{array}{c}106 \\
(86.88 \%)\end{array}$ & $\begin{array}{c}67 \\
(54.91 \%)\end{array}$ & $\begin{array}{c}2 \\
(1.63 \%)\end{array}$ & $\begin{array}{c}94 \\
(77.04 \%)\end{array}$ & $\begin{array}{c}76 \\
(62.29 \%)\end{array}$ & $\begin{array}{c}8 \\
(6.55 \%)\end{array}$ & $\begin{array}{c}56 \\
(45.90 \%)\end{array}$ & $\begin{array}{c}3 \\
(2.45 \%)\end{array}$ & $\begin{array}{c}39 \\
(31.96 \%)\end{array}$ & $\begin{array}{c}2 \\
(1.63 \%)\end{array}$ & $\begin{array}{c}44 \\
(36.06 \%)\end{array}$ & $\begin{array}{c}122 \\
(100 \%)\end{array}$ \\
\hline
\end{tabular}


STEC strains isolated from dysentery, fever, other clinical signs and non-diarrheic samples. The highest incidence of antimicrobial resistance in non-O157 STEC strains [9] was found for sulfisoxazole (36\%), tetracycline (32\%), streptomycin (29\%), ampicillin (10\%), trimethoprim (8\%), co-trimoxazole (8\%), chloramphenicol (7\%), kanamycin (7\%), piperacillin (6\%) and neomycin (5\%); these values are lower than the values reported in the present study. Jafari et al. [13] showed that diarrheagenic E. coli isolates of Iran had high resistance against amoxicillin and tetracycline $(75.5 \%)$ which was similar to our results. Similar Iranian investigations have been done previously [52-54]. Käppeli et al. [8] reported that the STEC antibiotic resistance rates against ampicillin, amoxicillin/clavulanic acid, cephalothin, cefpodoxime, cefuroxime, gentamicin, and tetracycline were $3.1 \%, 12.4 \%, 1 \%, 1 \%, 2.1 \%$, and $21.6 \%$, respectively which was similar to our findings.

Our results showed that resistance to at least one of the 12 antimicrobial drugs tested was identified in all (100\%) of the STEC strains, which is consistent with previous studies [8-10]. Our antimicrobial resistance data are in accordance with the results from a study in Spain, in which 238 (41\%) of 581 non-O157 STEC strains were resistant to at least one out of the 26 antimicrobial drugs that were tested [9].

The above data highlight large differences in the prevalence of STEC strains in the different studies, as well as differences in virulence genes and antibiotic resistance properties in the clinical samples. This could be related to differences in the type of sample (stool, blood, urine, meat, milk, vegetable and other clinical samples) tested, number of samples, method of sampling, experimental methodology, geographical area, antibiotic prescription preference among clinicians, antibiotic availability, and climate differences in the areas where the samples were collected, which would have differed between each study.

\section{Conclusions}

In conclusion, we identified a large number of virulence factors, serogroups, and antibiotic resistance genes and resistance to more than one antibiotic in the STEC strains isolated from diarrheic and non-diarrheic patients. Our data indicate that $\mathrm{O} 157$ and especially non-O157 STEC strains are predominant in Iranian diarrheic children. Marked seasonal variation in the serogroup distribution was also found. Our data revealed that the O26 serogroup, the stx1, stx2, eaeA and ehly putative virulence genes, the sul1, aac(3)-IV, aadA1, blaSHV and tetA antibiotic resistance genes, and resistance to penicillin, tetracycline, gentamicin and streptomycin were the most commonly detected characteristics of the STEC strains isolated from Iranian diarrheic and non-diarrheic children. Hence, judicious use of antibiotics is required by clinicians.

\section{Abbreviations}

E. coli: Escherichia coli; PCR: Polymerase chain reaction; EHEC: Enterohaemorrhagic Escherichia coli; AEEC: Attaching and effacing Escherichia coli; STEC: Shiga toxin-producing Escherichia coli; SPSS: Statistical package for the social sciences; CLSI: Clinical and laboratory standards Institute.

\section{Competing interests}

The authors declare that they have no competing interests.

\section{Authors' contributions}

DNA extraction, PCR, manuscript preparation, statistical analysis and project support were all performed by HM and FSD. Sample collections and coordination was performed by MJH, MH and MS. All authors have read and approved the final manuscript.

\section{Acknowledgements}

This work was supported by the Islamic Azad University, Shahrekord Branch-Iran. The authors would like to thank M. Dodi at the Microbiology Research Center of the Islamic Azad University of Flavarjan, and Dr. E. Tajbakhsh and Mr. M. Momeni at the Biotechnology Research Center of the Islamic Azad University of Shahrekord for their important technical and clinical support.

\section{Author details}

'Department of Microbiology, Shahrekord Branch, Islamic Azad University, P.O. Box 166, Shahrekord, Iran. ${ }^{2}$ Young Researchers and Elites Club, Islamic Azad University, Shahrekord Branch, Shahrekord, Iran. ${ }^{3}$ Molecular Biology Research Center, Baqiyatallah University of Medical Sciences, Tehran, Iran. ${ }^{4}$ Master of Science Microbiology, Flavarjan Branch, Islamic Azad University, Flavarjan, Iran.

Received: 22 October 2013 Accepted: 9 December 2013 Published: 11 December 2013

\section{References}

1. Thorpe CM: Shiga toxin-producing Escherichia coli infection. Clin Infect Dis 2004, 38(9):1298-1303.

2. Karch H, Tarr PI, Bielaszewska M: Enterohaemorrhagic Escherichia coli in human medicine. Int J Med Microbiol 2005, 295(6-7):405-418.

3. Wong CS, Jelacic S, Habeeb RL, Watkins SL, Tarr PI: The risk of the hemolytic-uremic syndrome after antibiotic treatment of Escherichia coli 0157:H7 infections. N Engl J Med 2000, 342(26):1930-1936.

4. Tarr PI, Gordon CA, Chandler WL: Shiga-toxin-producing Escherichia coli and haemolytic uraemic syndrome. Lancet 2005, 365(9464):1073-1086.

5. Bielaszewska M, Friedrich AW, Aldick T, Schürk-Bulgrin R, Karch H: Shiga toxin activatable by intestinal mucus in Escherichia coli isolated from humans: predictor for a severe clinical outcome. Clin Infect Dis 2006, 43(9):1160-1167.

6. Law D: Virulence factors of Escherichia coli 0157 and other Shiga toxin-producing. E. coli. J Appl Microbiol 2000, 88(5):729-745.

7. Schmidt H, Beutin L, Karch H: Molecular analysis of the plasmid-encoded hemolysin of Escherichia coli 0157:H7 strain EDL 933. Infect Immun 1995, 63(3):1055-1061.

8. Käppeli U, Hächler H, Giezendanner N, Beutin L, Stephan R: Human infections with non-0157 Shiga toxin-producing Escherichia coli, Switzerland, 2000-2009. Emerg Infect Dis 2011, 17(2):180-185.

9. Mora A, Blanco JE, Blanco M, Alonso MP, Dhabi G, Echeita A, González EA, Bernárdez MI, Blanco J: Antimicrobial resistance of Shiga toxin (verotoxin)-producing Escherichia coli 0157:H7 and non-0157 strains isolated from humans, cattle, sheep and food in Spain. Res Microbiol 2005, 156(7):793-806.

10. Schroeder CM, Meng J, Zhao S, DebRoy C, Torcolini J, Zhao C, McDermott PF, Wagner DD, Walker RD, White DG: Antimicrobial resistance of Escherichia coli O26, O103, 0111, 0128, and 0145 from animals and humans. Emerg Infect Dis 2002, 8(12):1409-1414.

11. Zali MR, Moez Ardalan K, Parcham Azad K, Nik-Kholgh B: Etiologies of acute diarrheal diseases in Iran. J Res Med Sci 2003, 7(4):346-356.

12. Rezaie Homami M, Salmanzadeh Ahrabi S, Moez Ardalan K, Habibi E, Edalatkhah H, Jafari F, Moez Ardalan S, Zolfagharian K, Moghaddam Golmohammadi A, Azimi Rad M: Epidemiology of bacterial-induced acute diarrhea in Varamin. Pejouhandeh Q Res J 2003, 8(7):467-474. 
13. Jafari F, Hamidian M, Rezadehbashi M, Doyle M, Salmanzadeh-Ahrabi S, Derakhshan F, Reza Zali M: Prevalence and antimicrobial resistance of diarrheagenic Escherichia coli and Shigella species associated with acute diarrhea in Tehran, Iran. Can J Infect Dis Med Microbiol 2009 20(3):e56-62.

14. Sabat G, Rose P, Hickey WJ, Harkin JM: Selective and sensitive method for PCR amplification of Escherichia coli 16S rRNA genes in soil. Appl Environ Microbiol 2000, 66(2):844-849.

15. Clinical and Laboratory Standards Institute (CLSI): Performance Standards for Antimicrobial Disk Susceptibility Tests, Approved standard-Ninth Edition (M2-A9). Wayne, PA: Clinical and Laboratory Standards Institute; 2006.

16. Heuvelink AE, van de Kar NC, Meis JF, Monnens LA, Melchers WJ: Characterization of verocytotoxin-producing Escherichia coli 0157 isolates from patients with haemolytic uraemic syndrome in Western Europe. Epidemiol Infect 1995, 115(1):1-14

17. Reischl U, Youssef MT, Kilwinski J, Lehn N, Zhang WL, Karch H, Strockbine NA: Real-time fluorescence PCR assays for detection and characterization of Shiga toxin, intimin, and enterohemolysin genes from Shiga toxin-producing Escherichia coli. J Clin Microbiol 2002, 40(7):2555-2565.

18. Brian MJ, Frosolono M, Murray BE, Miranda A, Lopez EL, Gomez HF, Cleary TG: Polymerase chain reaction for diagnosis of enterohemorrhagic Escherichia coli infection and hemolytic-uremic syndrome. J Clin Microbiol 1992, 30(7):1801-1806.

19. Idress M, Mussarat U, Badshah Y, Qamar R, Bokhari H: Virulence factors profile of drug-resistant Escherichia coli isolates from urinary tract infections in Punjab, Pakistan. Eur J Clin Microbiol Infect Dis 2010, 29(12):1533-1537.

20. Possé B, De Zutter L, Heyndrickx M, Herman L: Metabolic and genetic profiling of clinical 0157 and non-0157 Shiga-toxin-producing Escherichia coli. Res Microbiol 2007, 158(7):591-599.

21. DebRoy C, Fratamico PM, Roberts E, Davis MA, Liu Y: Development of PCR assays targeting genes in O-antigen gene clusters for detection and identification of Escherichia coli $\mathrm{O} 45$ and $\mathrm{O} 55$ serogroups. Appl Environ Microbiol 2005, 71(8):4919-4924.

22. Perelle S, Dilasser F, Grout J, Fach P: Identification of the O-antigen biosynthesis genes of Escherichia coli 091 and development of a 091 PCR serotyping test. J Appl Microbiol 2002, 93(5):758-764.

23. DebRoy C, Roberts E, Kundrat J, Davis MA, Briggs CE, Fratamico PM: Detection of Escherichia coli serogroups $\mathrm{O} 26$ and $\mathrm{O} 113$ by PCR amplification of the wzx and wzy genes. Appl Environ Microbiol 2004, 70(3):1830-1832.

24. Fratamico PM, Briggs CE, Needle D, Chen CY, DebRoy C: Sequence of the Escherichia coli 0121 O-antigen gene cluster and detection of enterohemorrhagic $E$. coli 0121 by PCR amplification of the wzx and wzy genes. J Clin Microbiol 2003, 41(7):3379-3383.

25. Shao J, Li M, Jia Q, Lu Y, Wang PG: Sequence of Escherichia coli 0128 antigen biosynthesis cluster and functional identification of an alpha-1,2-fucosyltransferase. FEBS Lett 2003, 553(1-2):99-103.

26. Randall LP, Cooles SW, Osborn MK, Piddock LJ, Woodward MJ: Antibiotic resistance genes, integrons and multiple antibiotic resistance in thirty-five serotypes of Salmonella enterica isolated from humans and animals in the UK. J Antimicrob Chemother 2004, 53(2):208-216.

27. Toro CS, Farfán M, Contreras I, Flores O, Navarro N, Mora GC, Prado V: Genetic analysis of antibiotic-resistance determinants in multidrugresistant Shigella strains isolated from Chilean children. Epidemiol Infect 2005, 133(1):81-86

28. Mammeri H, Van De Loo M, Poirel L, Martinez-Martinez L, Nordmann P. Emergence of plasmid-mediated quinolone resistance in Escherichia coli in Europe. Antimicrob Agents Chemother 2005, 49(1):71-76.

29. Van TT, Chin J, Chapman T, Tran LT, Coloe PJ: Safety of raw meat and shellfish in Vietnam: an analysis of Escherichia coli isolations for antibiotic resistance and virulence genes. Int J Food Microbiol 2008, 124(3):217-223.

30. Louisiana Office of Public Health: Infectious disease epidemiology section. E. coli-O157 2012, H7:3.

31. García-Aljaro C, Muniesa M, Jofre J, Blanch AR: Prevalence of the stx2 gene in coliform populations from aquatic environments. Appl Environ Microbiol 2004, 70(6):3535-3540.

32. Rivas M, Miliwebsky E, Balbi L, García B, Leardini N, Tous M, Chillemi G, Baschkier A, Strugo L: Intestinal bleeding and occlusion associated with Shiga toxin-producing Escherichia coli 0127:H21. Med (B Aires) 2000, 60(2):249-252.
33. Salmanzadeh-Ahrabi S, Habibi E, Jaafari F, Zali MR: Molecular epidemiology of Escherichia coli diarrhoea in children in Tehran. Ann Trop Paediatr 2005, 25(1):35-39

34. Alikhani MY, Mirsalehian A, Fatollahzadeh B, Pourshafie MR, Aslani MM: Prevalence of enteropathogenic and shiga toxin-producing Escherichia coli among children with and without diarrhoea in Iran. J Health Popul Nutr 2007, 25(1):88-93

35. Sang WK, Boga HI, Waiyaki PG, Schnabel D, Wamae NC, Kariuki SM: Prevalence and genetic characteristics of Shigatoxigenic Escherichia coli from patients with diarrhoea in Maasailand. Kenya. J Infect Dev Ctries 2012, 6(2):102-108.

36. Kim YJ, Kim JH, Hur J, Lee JH: Isolation of Escherichia coli from piglets in South Korea with diarrhea and characteristics of the virulence genes. Can J Vet Res 2010, 74(1):59-64.

37. Paton AW, Paton JC: Detection and characterization of Shiga toxigenic Escherichia coli by using multiplex PCR assays for stx1, stx2, eaeA, enterohemorrhagic E. coli hlyA, rfb0111, and rfbO157. J Clin Microbiol 1998, 36(2):598-602.

38. Scaletsky IC, Aranda KR, Souza TB, Silva NP, Morais MB: Evidence of pathogenic subgroups among atypical enteropathogenic Escherichia coli strains. J Clin Microbiol 2009, 47(11):3756-3759.

39. Shams S, Haghi Ashtiani MT, Nasrollahi L, Shahsiah R, Monajemzadeh M, Tahbaz Lahafi B, Alaie Alamooti A: Frequency of Shiga toxin-producing genes of Escherichia coli isolated from diarrheic stools of Iranian children by PCR. Iranian J Pediatr 2013, 23(6):637-642.

40. Aslani MM, Bouzari S: Characterization of virulence genes of non-0157 Shiga toxin-producing Escherichia coli isolates from two provinces of Iran. Jpn J Infect Dis 2009, 62(1):16-19.

41. Bonyadian M, Momtaz H, Rahimi E, Habibian R, Yazdani A, Zamani M: Identification \& characterization of Shiga toxin-producing Escherichia coli isolates from patients with diarrhoea in Iran. Indian J Med Res 2010, 132(3):328-331.

42. Kleanthous H, Smith HR, Scotland SM, Gross RJ, Rowe B, Taylor CM, Milford DV: Haemolytic uraemic syndromes in the British isles, 1985-8: association with verocytotoxin producing Escherichia coli. Part 2: microbiological aspects. Arch Dis Child 1990, 65(7):722-727.

43. Ostroff SM, Tarr PI, Neill MA, Lewis JH, Hargrett-Bean N, Kobayashi JM: Toxin genotypes and plasmid profiles as determinants of systemic sequelae in Escherichia coli 0157:H7 infections. J Infect Dis 1989, 160(6):994-998.

44. Johnson KE, Thorpe CM, Sears CL: The emerging clinical importance of non-0157 Shiga toxin-producing Escherichia coli. Clin Infect Dis 2006, 43(12):1587-1595.

45. Andreoli SP, Trachtman H, Acheson DW, Siegler RL, Obrig TG: Hemolytic uremic syndrome: epidemiology, pathophysiology, and therapy. Pediatr Nephrol 2002, 17(4):293-298

46. Aslani MM, Alikhani MY: Serotypes of Enteropathogenic Escherichia coli isolated from children under 5 years of age. Iranian J Publ Health 2009 38(3):70-77.

47. Alikhani MY, Mirsalehian A, Aslani MM: Detection of typical and atypical enteropathogenic Escherichia coli (EPEC) in Iranian children with and without diarrhoea. J Med Microbiol 2006, 55(Pt 9):1159-1163.

48. Elliott EJ, Robins-Browne RM, O'Loughlin EV, Bennett-Wood V, Bourke J, Henning P, Hogg GG, Knight J, Powell H, Redmond D: Nationwide study of haemolytic uraemic syndrome: clinical, microbiological, and epidemiological features. Arch Dis Child 2001, 85(2):125-131.

49. Rivas M, Miliwebsky E, Chinen I, Roldán CD, Balbi L, García B, Fiorilli G, Sosa-Estani S, Kincaid J, Rangel J, Griffin PM: Characterization and epidemiologic subtyping of Shiga toxin-producing Escherichia coli strains isolated from hemolytic uremic syndrome and diarrhea cases in Argentina. Foodborne Pathog Dis 2006, 3(1):88-96.

50. Momtaz H, Karimian A, Madani M, Safarpoor Dehkordi F, Ranjbar R, Sarshar M, Souod N: Uropathogenic Escherichia coli in Iran: serogroup distributions, virulence factors and antimicrobial resistance properties. Ann Clin Microbio Antimicrob 2013, 12:8

51. Momtaz H, Safarpoor Dehkordi F, Rahimi E, Ezadi H, Arab R: Incidence of Shiga toxin-producing Escherichia coli serogroups in ruminant's meat. Meat Sci 2013, 95(2):381-388

52. Fazeli $H$, Salehi R: Antibiotic resistance pattern in shiga toxin producing Escherichia coli isolated from diarrheal patients in Al-Zahra Hospital, Isfahan, Iran. Res Pharmacoceut Sci 2007, 2(1):29-33. 
53. Kalantar E, Alikhani MY, Naseri MH, Torabi V: Antibiotic resistance patterns of STEC and ETEC strains: a study on frozen foods of animal origin and children with acute diarrhea. J Microbiol Infect Dis 2013, 3(1):31-35.

54. Alikhani MY, Hashemi SH, Aslani MM, Farajnia S: Prevalence and antibiotic resistance patterns of diarrheagenic Escherichia coli isolated from adolescents and adults in Hamedan, West Iran. Iran J Microbiol 2013, 5(1):42-47.

doi:10.1186/1757-4749-5-39

Cite this article as: Momtaz et al:: Serogroups, virulence genes and antibiotic resistance in Shiga toxin-producing Escherichia coli isolated from diarrheic and non-diarrheic pediatric patients in Iran. Gut Pathogens 2013 5:39.

\section{Submit your next manuscript to BioMed Central and take full advantage of:}

- Convenient online submission

- Thorough peer review

- No space constraints or color figure charges

- Immediate publication on acceptance

- Inclusion in PubMed, CAS, Scopus and Google Scholar

- Research which is freely available for redistribution 